\title{
Severe Abdominal Pain Caused by Lead Toxicity without Response to Oral Chelators: A Case Report
}

\author{
Hassan Vossoughinia ${ }^{1}$, Ali Pourakbar ${ }^{2}$, Samaneh Esfandiari ${ }^{3 *}$, Masoud Sharifianrazavi ${ }^{2}$
}

1. Associate Professor, Gastroenterology and Hepatology Department, Mashhad University of Medical Sciences, Mashhad, Iran

2. Gastroenterology Fellow, Department of Gastroenterology and Hepatology, Ghaem Hospital, Mashhad University of Medical Sciences, Mashhad, Iran.

3. Assistant Professor of Occupational Medicine, Department of Occupational and Environmental Medicine, Mashhad University of Medical Science, Mashhad, Iran

\footnotetext{
* Corresponding Author:

Samaneh Esfandiari, MD

Assistant Professor, Department of Occupational Medicine, Department of Occupational and Environmental Medicine, Mashhad University of Medical Science, Mashhad, Iran

Telfax: + 985138002176

Email: esfandiaris911@mums.ac.ir

Received: 09 May 2015

Accepted: 29 Jul. 2015
}

\section{ABSTRACT}

A 19-year-old woman was referred to the Emergency Surgery Department with severe abdominal pain, icterus, and anemia. The patient's clinical and paraclinical findings in addition to her occupational and social history, convinced us to assay blood lead level (BLL), which was $41 / 5 \mu \mathrm{g} / \mathrm{dL}$. Therefore toxicology consult was performed to treat lead toxicity.

Recheck of the BLL showed the level as 53/7 $\mu \mathrm{g} / \mathrm{dL}$. So oral chelator with succimer was started. Despite consumption of oral chelator, there was no response and the pain continued. Because our repeated evaluations were negative, we decided to re-treat lead poisoning by intravenous and intramuscular chelators. Dimercaprol (BAL) + calcium EDTA was started, and after 5 days, the pain relieved dramatically and the patient was discharged.

We recommend more liberal lead poisoning therapy in symptomatic patients, and also suggest parenteral chelator therapy, which is more potent, instead of oral chelators in patients with severe symptoms.

\section{KEYWORDS}

Abdominal Pain: Lead Toxicity; Oral Chelators

Please cite this paper as:

Vossoughinia H, Pourakbar A, Esfandiari S, Sharifianrazavi M. Severe Abdominal Pain Caused by Lead Toxicitywithout Response to Oral Chelators: A Case Report. Middle East J Dig Dis 2015;8:67-72. DOI :10.15171/mejdd.2016.10

\section{INTRODUCTION}

Lead is widely available in the environment. Lead poisoning has been recognized as a major public health risk, particularly in developing countries. ${ }^{1}$ Lead serves no useful biological function in humans. The release of lead into the environment from automobile emissions, lead-based paint or kitchenware, incineration of waste containing lead additives, and the burning of coal and its subsequent bioaccumulation has had profound public health implications. ${ }^{2}$ Air, dust, soil, drinking water, cosmetics, dietary and herbal supplements, and soiled parental work clothing are additional potential sources of exposure to lead for children and for all populations. ${ }^{3}$

Opioid abuse that is common in Iran is another source. ${ }^{4}$ Opioid adulteration including lead, thallium, and steroids are commonly reported. ${ }^{5-7}$ It has been shown that adulteration of lead opioids could result in severe lead toxicities. ${ }^{7,8}$

Lead affects major organ systems in the body including hematopoietic, gastrointestinal, respiratory, renal, nervous, and cardiovascular systems mainly through increased oxidative stress, ionic mechanisms, and apoptosis..$^{1,9-12}$ Lead exposure occurs mainly through the respira- 
tory and gastrointestinal systems, and it is stored in soft tissues as well as bones. Autopsy studies have suggested that $33 \%$ of the absorbed lead is stored in the liver. ${ }^{12}$ Ingestion of lead is one of the primary causes of its hepatotoxic effects. . $^{1,12}$

Currently, there are very few case reports, which have described lead induced hepatotoxicity in humans. Mokhtarifar and colleagues, reported the first case from Mashhad last year, in which intrahepatic cholestasis caused by lead toxicity was described. ${ }^{13-15}$

Although, acute abdominal pain of unclear origin, caused by lead poisoning in patients with opium addiction, has been reported, ${ }^{16}$ we report a case with environmental lead toxicity with severe abdominal pain whose pain responded only to intravenous + intramuscular chelator therapy at a lead level that was lower than recommended level for parenteral chelator therapy in various references. ${ }^{2,3}$ According to toxicology consult, the patient was treated only with oral chelator agents as it was mentioned in the toxicology references for the lead level of our patient ${ }^{17,18}$ The low potent oral agent could not resolve the pain and as a result additional unnecessary. tests were done for the patient.

\section{CASE REPORT}

A 19-years-old single woman presented to the Emergency Surgery Department of Ghaem Hospital in Mashhad, northeast Iran with abdominal pain, icterus, and anemia. She was admitted to the Surgery Department with acute abdominal pain.

There was no significant disease in her medical history but in her social history she had addiction to hookah. She was a pilotage student and was working several hours of a day in the airport. There was no history of drug consumption in the recent months to justify related abnormal liver function tests.

Location of pain was in epigastrium with radiation to the left lower quadrant area. The pain was persistent from 4 days ago, without relation to oral feeding. The patient had nausea and vomiting intermittently and also had anorexia but without significant weight loss.

The patient's physical examination revealed stable hemodynamic, and mildly icteric sclera. In abdominal examination, tenderness of LLQ (left lower quadrant) in deep palpation without rigidity, or rebound tenderness was revealed. The other examinations such as chest and bowel sounds and also digital rectal examination were normal.

Laboratory findings included a normocytic anemia and direct bilirubinemia (table 1).

Plain abdominal radiography was normal. U1trasound study of the abdomen and pelvis revealed several lymphadenopathies in the right lower quadrant and anterior to right psoas muscle. The biggest size of the lymph nodes was $14 \times 7 / 5 \mathrm{~mm}$.

Abdominal pain subsided with conservative management in the Emergency Surgery Department, and the patient was referred to gastroenterologists for more evaluations because of abnormal liver function tests. Other potential causes of icter and abnormal aspartate transaminase and alanine transaminase including sepsis, viral hepatitis, autoimmune diseases, primary biliary cirrhosis, and primary sclerosing cholangitis were ruled out with proper laboratory and imaging modalities (table 1).

A new abdominopelvic sonography revealed normal liver and biliary tract except large amounts of sludge in the gallbladder. Gall bladder wall thickness was normal. Spleen, pancreas, retroperitoneum, and other abdominal organs were normal. Both kidneys and urinary bladder, uterus, and endometrium were normal. Ovaries size was $40 \times 26 \mathrm{~mm}$ with several follicles (all $<10 \mathrm{~mm}$ ). There were five 11-13 mm adenopathies in the right lower quadrant.

Colonoscopy was normal until cecum. Terminal ileum was normal and biopsy of ileum revealed chronic inflammation, no villous atrophy, and no intraepithelial lymphocytosis.

According to hookah consumption and an unreliable history for addiction to opioids, serum lead level was examined to rule out lead poisoning. The serum lead level was $415 / 6 \mu \mathrm{g} / \mathrm{L}(41 / 5 \mu \mathrm{g} / \mathrm{dL})$ with normal range of $<150 \mu \mathrm{g} / \mathrm{L}$, thus hematology and toxicology consult was performed.

Causes of anemia including iron deficiency and hemolytic anemia were excluded by checking serum iron, total iron binding capacity (TIBC), LDH(Lactate dehydrogenase), and reticulocyte 
Table 1: First laboratory data of the patient with lead toxicity

\begin{tabular}{|c|c|c|c|c|c|c|c|c|c|c|c|}
\hline Blood index & Case & $\begin{array}{c}\text { Nor- } \\
\text { mal } \\
\text { range }\end{array}$ & $\begin{array}{l}\text { Blood } \\
\text { index }\end{array}$ & Case & $\begin{array}{c}\text { Nor- } \\
\text { mal } \\
\text { range }\end{array}$ & $\begin{array}{l}\text { Blood } \\
\text { index }\end{array}$ & Case & $\begin{array}{c}\text { Normal } \\
\text { range }\end{array}$ & $\begin{array}{l}\text { Blood } \\
\text { index }\end{array}$ & Case & $\begin{array}{c}\text { Normal } \\
\text { range }\end{array}$ \\
\hline WBC & 7.5 & $\begin{array}{c}4000- \\
1100\end{array}$ & Urea & 30 & $25-50$ & $\begin{array}{c}\text { Lipase } \\
(\mathrm{U} / \mathrm{L})\end{array}$ & 44 & $\begin{array}{l}\text { Up to } \\
60\end{array}$ & $\mathrm{Na}$ & 140 & $135-145$ \\
\hline Neutrophils & 80 & & $\begin{array}{l}\text { AST } \\
(\mathrm{U} / \mathrm{L})\end{array}$ & 48 & $5-40$ & ESR & 8 & $\mathrm{~F}<20$ & $\mathrm{~K}$ & 4 & $3.5-5.3$ \\
\hline Lymphocyte & 20 & & $\begin{array}{l}\text { ALT } \\
(\mathrm{U} / \mathrm{L})\end{array}$ & 45 & $5-40$ & HbsAg & Neg & & $\mathrm{Ca}$ & 9.3 & $8.5-10.5$ \\
\hline $\mathrm{RBC}$ & 3.72 & & $\begin{array}{l}\text { ALP } \\
(\mathrm{U} / \mathrm{L})\end{array}$ & 97 & $\begin{array}{l}64- \\
306\end{array}$ & Anti-HCV & Neg & & $\mathrm{Mg}$ & 1.8 & \\
\hline $\mathrm{Hb}$ & 9.6 & & $\begin{array}{c}\mathrm{PT} \\
(\mathrm{sec})\end{array}$ & 12 & $11-14$ & Anti-HAV & Neg & & SPEP & NL & \\
\hline HCT & 30 & $36-47$ & $\begin{array}{l}\text { PTT } \\
(\mathrm{sec})\end{array}$ & 35 & $25-40$ & ANA & 1 & $0-1.2$ & & & \\
\hline $\mathrm{MCV}$ & 80.6 & & INR & 1 & 1 & AMA & NL & & & & \\
\hline $\mathrm{MCH}$ & 25.8 & $25-33$ & $\begin{array}{l}\mathrm{LDH} \\
(\mathrm{U} / \mathrm{L})\end{array}$ & 264 & $\begin{array}{c}230- \\
460\end{array}$ & $\begin{array}{l}\text { Anti- } \\
\text { LKM }\end{array}$ & $\mathrm{NL}$ & & & & \\
\hline PLT & 284000 & & Iron & 127 & $\begin{array}{l}57- \\
140 \\
\end{array}$ & P-ANCA & NL & & & & \\
\hline Reticulocyte & 1.8 & & TIBC & 336 & $\begin{array}{c}250- \\
440\end{array}$ & $\begin{array}{c}\text { CEA } \\
\mathrm{ng} / \mathrm{ml}\end{array}$ & 0.9 & $\begin{array}{c}\text { Up to } \\
4.5\end{array}$ & & & \\
\hline $\mathrm{FBS}(\mathrm{mg} / \mathrm{dl})$ & 101 & 110 & $\begin{array}{l}\text { Total Bil } \\
(\mathrm{mg} / \mathrm{dl})\end{array}$ & 3.9 & $<1.1$ & AFP & 0.8 & & & & \\
\hline U/A & NL & & $\begin{array}{c}\text { Direct Bil } \\
(\mathrm{mg} / \mathrm{dl})\end{array}$ & 0.6 & $<0.2$ & $\begin{array}{l}\mathrm{Ig} \mathrm{G4} \\
(\mathrm{mg} / \mathrm{dl})\end{array}$ & 24.3 & & & & \\
\hline $\mathrm{CR}(\mathrm{mg} \%)$ & 0.6 & $\begin{array}{l}\text { Up to } \\
1 / 5\end{array}$ & $\begin{array}{c}\text { Amylase } \\
\text { (U/L) }\end{array}$ & 96 & $\begin{array}{c}\text { Up to } \\
90\end{array}$ & CA- 125 & 7 & & & & \\
\hline
\end{tabular}

Abbreviations: WBC: White blood cells; RBC: Red blood cells; Hb: Hemoglobin; HCT: Hematocrit; MCV: Mean corpuscular volume FBS: Fasting blood sugar CR: Creatinine; AST: Aspartate transaminase; ALT: Alanine transaminase; ALP: Alkaline phosphatase; Total Bil: Total bilirubin; Direct Bil: Direct bilirubin; ESR: Erythro $\neg$ cyte sedimentation rate; U/A: Urine analysis; Hbs Ag: Hepatitis B surface antigen; Anti-HCV: Antibody hepatitis $\mathrm{C}$ virus; Anti-HAV: Antibody hepatitis A virus; ANA: Antinuclear antibodies; ASMA: anti-smooth muscle an $\neg$ tibodies; AMA: anti-mitochondrial antibodies; Anti-LKM1: anti-liver kidney microsome 1 antibodies; P-ANCA: peri $\neg$ nuclear anti-neutrophil cytoplasmic antibodies; SPEP: serum protein electrophoresis; NL: Normal; AFP: Alpha feto protein

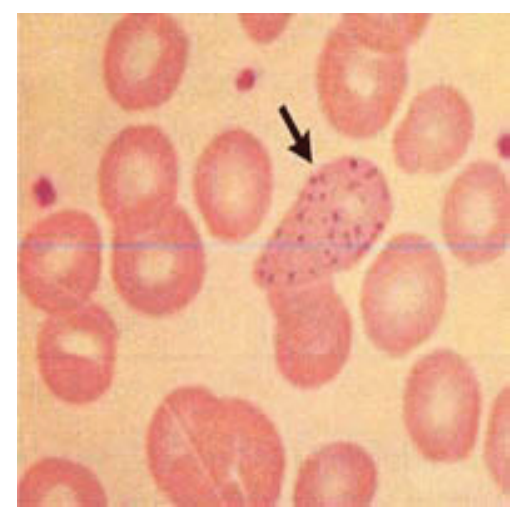

Fig.1: Basophilic stippling

count levels (table 1).

Morphology of RBC in peripheral blood smear showed anisocytosis(+), microcytosis(+), hypochro- $\operatorname{mia}(+)$, ovalocytosis(+), and ostomatocytosis $(+)$. Basophilic stippling was also seen in the peripheral smear, which can be seen in lead poisoning (figure1).

Toxicology consult was done, and serum lead level was rechecked, which revealed $537 \mu \mathrm{g} / \mathrm{L}$ $(53 / 7 \mathrm{mg} / \mathrm{dL})$. Because of the serum lead level that was between 40 to $70 \mu \mathrm{g} / \mathrm{dL}$ and having considered the toxicology references ${ }^{18,20}$ only oral chelator (succimer) was recommended for the patient.The recommended dose was $10 \mathrm{mg} / \mathrm{kg}$ three times a day for five days, followed by $10 \mathrm{mg} / \mathrm{kg}$ twice a day for two weeks (maximum $500 \mathrm{mg} / \mathrm{dose}$ ).

Despite oral chelator consumption the pain continued, for which we decided to perform more evaluation for the patient. We found mild serum 
amylase and lipase elevation in the repeated lab tests (table 2). And according to the presence of sludge in the abdominal sonography of gallbladder, endosonography was done for more evaluation of common bile duct (CBD). The report read :"there were multiple hyperechoic lesions and one small stone with posterior shadow inside the distal part of CBD. Diameter of CBD was 3/6 mm. pancreas was normal. Gall bladder had multiple small hyperechoic lesions".

Because of these findings and the presence of severe abdominal pain, endoscopic retrograde cholangiopancreaticography (ERCP) was done. ERCP revealed no dilation of $\mathrm{CBD}$, so sphincterotomy was done and sludges were extracted.

Despite these therapeutic managements, the abdominal pain deteriorated during the admission, and gradually did not respond to ordinary analgesics, and only opioid analgesics could relief the pain in the last nights of admission in the GI ward. Surgical consultation was done, by which laparoscopy was recommended to approach to the unknown origin of continuous pain and also to the lymphadenopathies, which were noted in the abdominal sonographies. The patient underwent laparascopy. Its report read: "small intestine from proximal to distal was investigated which was normal but some lymphadenopathies was seen in the mesenter. Stomach, liver, uterus, ovaries, were normal.Cholecystectomy was done and biopsies obtained from the lymphnodes, liver and peritoneum." Pathological evaluation of the specimens revealed :1-cholecystectomy: acute on chronic cholecystitis, 2-mesenteric lymph node: reactive, 3- wedge liver biopsy: without significant pathologic changes, 4-labeled as peritoneal biopsy: fibromuscular tissue.

Conservative management was done after surgery, but the pain continued. Because of the patient's job in the airport, consultation with occupational medicine specialist was done, who recommended re-evaluation for lead poisoning considering her work place that is a source of environmental lead poisoning and also history of substance abuse (hookah addiction) and unreliable history for probably opioid addiction. Therefore the patient was admit- ted to toxicology ward.

At the toxicology ward, BLL was rechecked, which was $54 \mu \mathrm{g} / \mathrm{dL}$. Because of no response to previous oral chelator therapy in the same BLL, and the severe suspicious to lead poisoning as the cause of the abdominal pain, intravenous (IV) and intramuscular (IM) chelator therapy were recommended.

Dimercaprol or BAL (also referred to as British antilewisite) in conjunction with calcium EDTA was started for the patient. The recommended dose for BAL was $4 \mathrm{mg} / \mathrm{kg}$ to be injected deep IM every 4 hours for 3 days, in conjunction with edetate calcium disodium with the second dimercaprol dose; $25-50 \mathrm{mg} / \mathrm{kg} /$ day, IV for 5 days. A maximum dose of $3000 \mathrm{mg}$ was considered for calcium EDTA. After 3 days of the treatment, clinical findings including nausea, vomiting, and abdominal pain subsided and finally the pain relieved dramatically. The patient was discharged after 5 days of BAL prescription with maintenance therapy with oral succimer $(10 \mathrm{mg} / \mathrm{kg}$ twice a day for two weeks).

The patient was recommended to avoid substance abuse (hookah consumption), and also she was referred to occupational and environmental medicine specialists ${ }^{18,20}$ to evaluate the relationship between lead toxicity and her working environment. She was visited again 10 days later. There was no icterus, pain, or new signs or symptoms. New laboratory findings were all in normal range. She was recommended for monthly follow-up visits for six months (table 2).

\section{DISCUSSION}

This report is another piece of evidence showing the relationship between lead poisoning and acute abdominal pain. Hepatotoxicity caused by lead exposure has been already reported. ${ }^{21,22} \mathrm{Ab}$-dominal pain and anemia have also been reported, particularly in areas where opioid use or air lead contamination is common. ${ }^{7,8,14,16}$

Despite of resolving the acute abdominal pain with oral chelators in previous case reports, Our case did not respond to oral chelator agents, hence underwent some unnecessary invasive evaluations. But our patient responded dramatically to only 5 
Table 2: Laboratory finding fluctuations

\begin{tabular}{|c|c|c|c|c|c|}
\hline Variables & $\begin{array}{l}\text { Day } 1 \text { (Admission in } \\
\text { surgery ward) }\end{array}$ & $\begin{array}{c}\text { Day } 5 \\
\text { (Admission } \\
\text { in GI ward) }\end{array}$ & $\begin{array}{l}\text { Day } 15 \text { (Admission in } \\
\text { toxicology ward) }\end{array}$ & $\begin{array}{c}\text { Day 20 } \\
\text { (Discharged) }\end{array}$ & $\begin{array}{c}\text { DAY 30 } \\
\text { (Outpatient } \\
\text { re-evaluation) }\end{array}$ \\
\hline $\mathrm{AST},(\mathrm{IU} / \mathrm{dL})$ & 48 & 50 & & & 32 \\
\hline ALT, (IU/dL) & 45 & 61 & & & 38 \\
\hline ALP, (IU/dL) & 97 & 116 & & & 125 \\
\hline Total Bilirubin, (mg/dL) & 3.9 & 2.1 & & & 1.4 \\
\hline $\begin{array}{l}\text { Direct Bilirubin, } \\
(\mathrm{mg} / \mathrm{dL})\end{array}$ & 0.6 & 0.3 & & & 0.3 \\
\hline Amylase & 96 & 208 & & & \\
\hline Lipase & 44 & 85 & & & \\
\hline $\begin{array}{l}\text { Serum lead level, } \\
(\mu \mathrm{g} / \mathrm{dL})\end{array}$ & & 41.5 and 53.7 & 54 & 22 & 14 \\
\hline
\end{tabular}

Abbreviations: ALT, Alanine amino transferase; ALP, alkaline phosphatase; AST, Aspartate amino transferase

days IV+IM chelators therapy in second toxicology consult.

Despite of Some references ${ }^{2,3,17,18}$ (for example, Goldfrank textbook of toxicology ${ }^{17}$ ) which recommend treatment for lead poisoning in upper lead levels; We recommend more liberal chelator therapy in symptomatic patients with lead poisoning as is noted in the new version of Up to date. ${ }^{20} \mathrm{We}$ also recommend parenteral chelator therapy, which is more potent than oral chelators in patients with severe signs and symptoms of lead poisoning, as it is mentioned in Up to date. ${ }^{20}$

There are several guidelines and recommendations for chelation therapy in lead poisoning, for excample;

Goldfrank,s textbook of toxicology emergencies recommends no treatment for patients with lead level below $70 \mathrm{mg} / \mathrm{dl} .{ }^{17}$

Pranay et al recommended IV therapy is preferable for persons with BLLs of $70 \mu \mathrm{g} / \mathrm{dL}$ or higher 18 Use the combination of dimercaprol and $\mathrm{CaNa} 2$ EDTA with BLLs of $70 \mu \mathrm{g} / \mathrm{dL}$ or higher and in the presence of lead encephalopathy. ${ }^{18}$ In adults, consider chelation therapy for patients with BLLs of $70 \mu \mathrm{g} / \mathrm{dL}$ or higher. Also consider chelation therapy in symptomatic adults with BLLs exceeding $50 \mu \mathrm{g} / \mathrm{dL} .^{18}$

As mentioned above some authors recommend chelation therapy in higher BLL, while internal medicine reference "up to date" 20 recommends; "In general, chelation should be initiated for individuals with BLLs greater than $100 \mu \mathrm{g} / \mathrm{dL}(4 / 83 \mu \mathrm{mol} / \mathrm{L}),{ }^{18}$ and should also be considered for levels between 80 to $100 \mu \mathrm{g} / \mathrm{dL}$ in asymptomatic individuals and for BLLs between 50 to $80 \mu \mathrm{g} / \mathrm{dL}$ ( $2 / 41$ to $3 / 86 \mu \mathrm{mol} / \mathrm{L}$ ) in individuals with lead-related symptoms . In addition, sometimes consider chelation in persons with even lower BLLs [eg, $\geq 40 \mu \mathrm{g} / \mathrm{dL}(1 / 93 \mu \mathrm{mol} / \mathrm{L})]$ if they have continued symptoms and elevated BLLs after two weeks of removal from exposure." 20

There are four major chelator agents that are used for treatment of lead poisoning:

Succimer, or meso 2,3-dimercaptosuccinic acid (DMSA), is an analogue of dimercaprol used in lead poisoning. It has high sensitivity for lead, but its ability to chelate essential trace metals is low. It is available as $100-\mathrm{mg}$ capsules. Its main indication is for persons whose BLLs are $45 \mu \mathrm{g} / \mathrm{dL}$ or higher. ${ }^{18}$

Rogan and colleagues noted ${ }^{23,24}$ that succimer was a water-soluble, oral chelating agent that was appropriate for use with BLLs higher than $45 \mu \mathrm{g} / \mathrm{dL}$.

D-penicillamine is a second-line oral chelating agent, although it is not approved by the US Food and Drug Administration (FDA) for use in lead poisoning. ${ }^{18}$

Calcium disodium Edetate (CaNa2 EDTA) is another chelating agent. It should never be used as the sole agent in patients manifesting with lead encephalopathy, because it does not cross the bloodbrain barrier and can potentially lead to exacerbation of lead encephalopathy. Dimercaprol (BAL), which does cross the blood-brain barrier should be administered first. ${ }^{18}$

Dimercaprol (BAL), which is also referred to as 
British antilewisite is another parenteral chelating agent recommended as an agent of first choice for patients with lead encephalopathy. With high BLLs (ie $>100 \mu \mathrm{g} / \mathrm{dL}$ ), it is used in conjunction with CaNa2 EDTA.

We noticed a significant difference in the BLLs in which the texts and guidelines recommend chelating therapy. Despite the internal medicine reference Up to date, 20 which consider chelation in persons with even lower BLLs (eg, $\geq 40 \mu \mathrm{g} / \mathrm{dL}$ ) in some situations, 20 toxicology and occupational and environmental medicine textbooks recommend chelation in higher BLLs .2,3,17,18

According to our experience on our case, we finally recommend more liberal lead poisoning therapy in symptomatic patients as is noted in the new version of Up to date and some guidelines $.18,20$,versus other texts that recommend treatment in higher lead levels .2,3,17

We also recommend parenteral chelator therapy in lower BLLs, instead of oral chelators in patients with severe signs and symptoms of lead poisoning, especially when oral chelators cannot resolve the signs and symptoms.

\section{CONFLICT OF INTEREST}

The authors declare no conflict of interest related to this work.

\section{REFERENCES}

1. Flora G, Gupta D, Tiwari A. Toxicity of lead: A review with recent updates. Interdiscip Toxicol 2012;5:47-58. DOI:10.2478/v10102-012-0009-2.

2. Richard L, Metals, Ladou J. Current occup and environ medicine ,McGraw - Hill, 2004;4:413-38.

3. Jacqueline MM, Rosenstock KL, textbook of clinical occup and environ medicine, Elsevier, 2005:967-78.

4. Afshari R, Majdzadeh R, Balali-Mood M. Pattern of acute poi $\neg$ sonings in Mashhad, Iran 1993-2000. J Toxicol Clin Toxicol 2004;42:965-75.

5. KousheshHR,AfshariR.Anewillicitopioiddependenceout $`$ break, evidence for a combination of opioids and steroids. Drug Chem Toxicol 2009;32:114-9. DOI:10.1080/01480540802588485.

6. Afshari R, Megarbane B, Zavar A. Thallium poisoning: one addi-tional and unexpected risk of heroin abuse. Clin Toxicol (Phila) 2012;50:791-2. DOI:10.3109/15563650.2012.713110.

7. Afshari R, Emadzadeh A. Short communication: case report on adulterated opium-induced severe lead toxicity. Drug Chem Toxi $\neg$ col 2010;33:48-9. DOI:10.3109/01480540903127340.

8. Karrari P, Mehrpour O, Abdollahi M. A systematic review on sta tus of lead pollution and toxicity in Iran; Guidance for preven-tive measures. Daru 2012;20:2. DOI:10.1186/1560-8115-20-2.
9. Khazdair MR, Boskabady MH, Afshari R, Dadpour B, Behforouz A, Javidi M, et al. Respiratory symptoms and pulmonary func $\neg$ tion testes in lead exposed workers. Iran Red Crescent Med J 2012;14:737-42. DOI:10.5812/ircmj.4134.

10. Samarghandian S, Borji A, Afshari R, Delkhosh MB, gholami A The effect of lead acetate on oxidative stress and antioxidant status in rat bronchoalveolar lavage fluid and lung tissue. Toxicol Mech Methods 2013;23:432-6. DOI:10.3109/15376516.2013.777136.

11. Balali-Mood M, Shademanfar S, Rastegar Moghadam J, Afshari R, Namaei Ghassemi M, Allah Nemati H, et al. Occupational lead poisoning in workers of traditional tile factories in Mashhad, Northeast of Iran. Int J Occup Environ Med 2010;1:29-38.

12. Mudipalli A. Lead hepatotoxicity \& potential health effects. In $\neg$ dian J Med Res 2007;126:518-27.

13. Mokhtarifar A, Mozaffari H,et al,Cholestasis and seizure due to lead toxicity:a case report, Hepat Mon 2013;13:12427. DOI:10.5812/hepatmon.12427.

14. Verheij J, Voortman J, van Nieuwkerk CM, Jarbandhan SV, Mulder CJ, Bloemena E. Hepatic morphopathologic findings of lead poi $\urcorner$ soning in a drug addict: a case report. $J$ Gastrointestin Liver Dis 2009;18:225-7.

15. Beattie AD, Mullin PJ, Baxter RH, Moore MR. Acute lead poison $\neg$ ing: an unusual cause of hepatitis. Scott Med J 1979;24:318-21.

16. Masoodi M, Zali MR, Ehsani-Ardakani MJ, MohammadAlizadeh AH, Aiassofi K, Aghazadeh, et al. Abdominal pain due to lead-contaminated opium: a new source of inorganic lead poisoning in Iran. Arch Iran Med 2006;9:72-5.

17. NE,Goldfrank LR,Hoffman RS,Howland MA,Lewin NA,Nelson LS,editors.Goldfrank,s Toxicology Emergencies. 8th ed. New York:McGraw-Hill ;2006.P.1265-68.

18. Goldman RH, Howard HU. Adult lead poisoning, 2015 up to date, www.uptodate.com,

19. Meybodi FA, Eslick GD, Sasani S, Abdolhoseyni M, Sazegar S, Ebra $\neg$ himi F. Oral opium: an unusual cause of lead poisoning. Singa $\neg$ pore Med J 2012;53:395-7.

20. Goldman RH,Howard HU, et al, adult lead poisoning, 2015 up to date, www.uptodate.com

21. Ochiai K, Jin K, Goryo M, Tsuzuki T, Itakura C. Pathomorphologic findings of lead poisoning in white-fronted geese(Anseralbi-frons). Vet Pathol 1993;30:522-8. DOI:10.1177/030098589303000605.

22. Papaioannou N, Vlemmas I, Balaskas N, Tsangaris T. Histo $\neg$ pathological lesions in lead intoxicated dogs. Vet Hum Toxicol 1998;40:203-7.

23. Rogan WJ, Dietrich KN, Ware JH, Dockery DW, Salganik M, Radcliffe J, et al. The effect of chelation therapy with succimer on neuropsychological development in children exposed to lead. Engl JMed 2001;344:1421-6. DOI:10.1056/NEJM200105103441902.

24. Gurer H, Ozgunes H, Neal R, Spitz DR, Ercal N. Antioxidant effects of N-acetylcysteine and succimer in red blood cells from leadexposed rats. Toxicology 1998;128:181-9. DOI:10.1016/S0300483X(98)00074-2. 